\title{
A Rare Case Report of Epigastric Heteropagus: Autosite with Cyanotic Congenital Heart Disease
}

\author{
Amar Taksande ${ }^{1 *}$, Akashi Gandhi ${ }^{2}$, Rewat Meshram ${ }^{3}$ and Amol Lohakare ${ }^{4}$ \\ ${ }^{1}$ Professor, Department of Pediatrics, Jawaharlal Nehru Medical College, India \\ ${ }^{2}$ Resident, Department of Pediatrics, Jawaharlal Nehru Medical College, India \\ ${ }^{3}$ Associate Professor, Department of Pediatrics, Jawaharlal Nehru Medical College, India \\ ${ }^{4}$ Senior Resident, Department of Pediatrics, Jawaharlal Nehru Medical College, India \\ Submission: April 26, 2018; Published: June 06, 2018
}

*Corresponding author: Amar M Taksande, Department of Pediatrics, Jawaharlal Nehru Medical College, Sawangi Meghe, Wardha, Maharashtra-442004, India, Email: amar.taksande@gmail.com

Abstract

Heteropagus, or "parasitic," twins are asymmetric conjoined twins, in which the host (autosite), is near normal and bears the parasite, which is totally dependent for growth on it. A parasitic twin who is attached to the epigastrium of the autosite is called as Epigastric heteropagus conjoined twins (EHTs) which are extremely rare. An associated congenital cardiac malformations, has been described in autosites. Here we report a rare case of epigastric heteropagus conjoined twins with cyanotic congenital heart disease (CHD) in the autosite.

Keywords: Parasitic twins; Heteropagus; Conjoined twins; Malformation

\section{Introduction}

Conjoined twins are the rarest form of monochrionic monoamniotic twins. Conjoined twins are usually of the symmetrical variety but at times they may be asymmetrical called heteropagus or parasitic twins. Parasitic or heteropagus twinsare an extremely rare condition, with an estimated incidence of 1-2 million live births [1]. The parasitic twin usually has supernumerary limbs without a functional heart or brain. In epigastric heteropagus conjoined twins, the parasite is attached to the autosite in the epigastric region mostly to the xiphi-sternal area. Here we report a rare case of epigastric heteropagus conjoined twins with Tetralogy of Fallot in the autosite.

\section{Case Report}

A 17-day-old full term boy was born to a 26yrs old mother was referred with epigastric parasitic twins. The baby was initially treated in other hospital but developed severe infection and then referred to our hospital. The mother had no history of drug intake, radiation exposure or illness during pregnancy. There was no history of twin delivery in the family. The antenatal period was uneventful. The parasite twin was attached to the epigastrium of the autosite. The parasite possessed rudimentary upper limbs, well developed lower limbs, pelvis, and genitals (Figure 1). However, the limbs of the parasite had neither active movement nor response to tactile stimulus. No head, neck or thoracic structures present. Omphalocele was present in the autosite as the attachment of parasite. The autosite twin was well developed, with intact bowel and bladder function (Figure 2). The autosite had a systolic cardiac murmur suggesting congenital heart disease. Infantogram was done suggestive of normal bowel shadows of the autosite twin and abdomen viscera was connected with the parasite twin. Ultrasonography of the autosite suggested normal genitourinary system. Echocardiography of the autosite showed tetralogy of fallot, having large ventricular-septal defect (right to left shunt), overriding of aorta and severe infundibular stenosis (gradient $60 \mathrm{mmHg}$ ). The baby died after a days of admission due to fulminant sepsis. The parents refused for a postmortem examination and thus detail evaluation was not done. 


\section{Journal of Cardiology \& Cardiovascular Therapy}
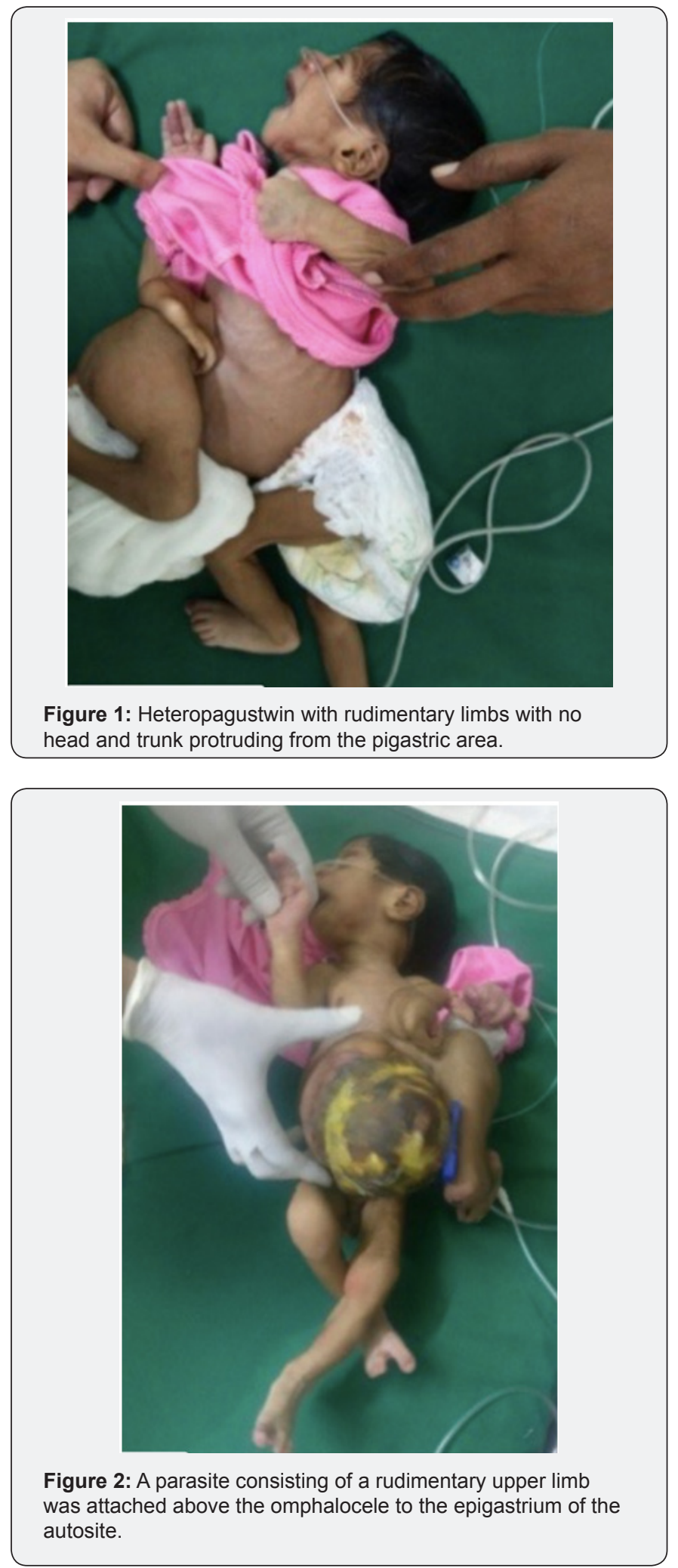

\section{Discussion}

Conjoined twins are rarely observed, but heteropagus conjoined twins occur even less frequently. Heteropagus twins are a rare form of conjoined twins where one of the twins is fully formed (autosite) and other is incomplete (parasite). Asymmetric and parasitic conjoined twins are anomalies of monochorionic monoamniotic twins [1,2]. The etiopathogenesis of conjoined twins are not very clear. There are two possible theories of which first is the fission theory in which incomplete fission due to division of the blastocyst beyond the $13^{\text {th }}$ day of fertilization. The second theory is the fusion hypothesis in which an incomplete division of a single zygote, the formation of two cellular masses within the blastocyst at the end of the second week post conception. In consequence, a sole embrionary structure is formed, but with a single yolk sac. The another theory mentioned was ischemic atrophy, in which the parasite twin is the result of an ischemic accident in the uterus, followed by the death and resorption of one of the foetuses $[3,4]$.

Conjoined twins are classified by the site of union and their symmetry and asymmetry. Symmetrical conjoined twins have two identically formed twins which are fused to each other at a certain site on both bodies. They may share viscera at that site and the nomenclature is according to the site of fusion i.e. craniopagus (Cranium), thoracopagus (fusion at chest), omphalopagus (fusion at anterior abdominal wall), is chiopagus (Pelvis/ischium), pyopagus (Buttocks/sacrum), or a combination of any of the above fusion. Heteropagusor parasitic twins are also called as asymmetrical conjoined twins in which the incompletely formed foetus 'parasite' is attached to the normally formed foetus or the 'autosite' at a particular point. The parasite is not completely formed and may only be evident by supernumerary limbs. The parasite usually does not have a functional brain or heart and does not share the host twin's gastrointestinal tract or liver but may have a rudimentary gastrointestinal tract or urinary system of its own with connection to that of the host [5].

Sharma et al. [6] reviewed the 39 cases of parasitic twins reported in 10-year interval and found that epigastric heteropagus was the most common anatomical type (59\%). Various congenital defects such as anencephaly, cleft lip, cleft palate, lumbosacral meningomyelocele, cardiac anomalies, gastrointestinal and urogenital anomalies may be associated with conjoined twins. Abdominal wall and spinal defects are commonly seen in omphalopagus and rachipagus twins, respectively. An associated congenital cardiac malformations, has been described in autosites. However, a single-ventricle heart anomaly in the autosite has been reported in a very few cases [4-7]. The cardiac anomalies was found in the autosite index case. Previously, only single reported cases of epigastric heteropagus twins with TOF inparasite, however this is the rare case of associated TOF in autosite [8]. Of all the heteropagus twins, epigastric heteropagus twins (EHT) are among the least documented cases in literature. In contrast to the female predominance of symmetrically conjoined twins, a male predominance is observed in EHT [6-9]. Antepartum diagnosis of parasitic twinning plays an important role in management. 
Therefore, heteropagus twins should be distinguished from more severe congenital malformations to avoid unnecessary termination. The diagnosis of Conjoined twins should be considered in any twin pregnancy that has single placenta, no visible separating amniotic membrane and polyhydramions that occurs frequently in conjoined twin pregnancy as compared with normal twin pregnancy [8]. Early referral and intensive management can help in achieving better survival in these babies. The ultimate outcome however will depend upon the associated malformation especially cardiac $[9,10]$. So, the improvement in paediatric cardiac care services can improve survival in babies having cardiac anomalies.

\section{Conclusion}

A parasitic twin in which one of the twins is severely defective and is depended on the vascular supply from its counterpart for its growth. To the best of our knowledge, this is the rare case report of Epigastric heteropagus case in the literature with a tetralogy of fallot in the autosite.

\section{References}

1. Ozkan Ulu H, Yilmaz Y, Sari FN, Altug N, Uras N, et al. (2011) An unusual case of heteropagus: Autosite with a complex cardiac malformation. Pediatr Neonatol 52(6): 358-360.
2. Gupta DK, Lall A, Bajpai M (2001) Epigastricheteropagus twins - a report of four cases. Pediatr Surg Int 17(5-6): 481-482.

3. Xie JT, Zhou L, Yang ZL, Sun HY (2012) Epigastric heteropagus conjoined twins: Two case studies and associated DNA analysis. Clinics (Sao Paulo) 67(5): 527-529.

4. Satter E, Tomita S (2008) A case report of an omphalopagus heteropagus (parasitic) twin. J Pediatr Surg 43(6): e37-e39.

5. Logrono R, Garcia Lithgow C, Harris C, Kent M, Meisner L (1997) Heteropagus conjoined twins due to fusion of two embryos: report and review. Am J Med Genet 73(3): 239-243.

6. Sharma G, Mobin SS, Lypka M, Urata MN (2010) Heteropagus (parasitic) twins: A review. J Pediatr Surg 45(12): 2454-2463.

7. Katke RD, Kurkal NS, Vinaik T, Pagare P (2015) A rare presentation of heteropagus conjoined twin: a case report with review of literature. Int J Reprod Contracept Obstet Gynecol 4(3): 851-854.

8. Husain AN, Muraskas J, Lambert G, Dado D, Lynch J (1989) Parasitic conjoined twins with omphalocele and tetralogy of fallot. Pediatr Pathol 9(3): 321-328.

9. Spitz L (2005) Conjoint twins review. Prenat Diagn 25(9): 814-819.

10. Bhansali M, Sharma DB, Raina VK (2005) Epigastricheteropagus twins: 3 cases reports with review of literature. J Pediatr Surg 40(7): 12041208.

\section{Your next submission with Juniper Publishers} will reach you the below assets

- Quality Editorial service

- Swift Peer Review

- Reprints availability

- E-prints Service

- Manuscript Podcast for convenient understanding

- Global attainment for your research

- Manuscript accessibility in different formats

( Pdf, E-pub, Full Text, Audio)

- Unceasing customer service

Track the below URL for one-step submission https://juniperpublishers.com/online-submission.php 